\title{
IN SEARCH OF THE TOMB OF SULTAN SÜLEYMAN IN SZIGETVÁR
}

\author{
PÁL FODOR-NORBERT PAP \\ Institute of History, Research Centre for the Humanities, \\ Hungarian Academy of Sciences, \\ H-1097 Budapest, Tóth Kálmán u. 4., Hungary \\ e-mail: fodor.pal@btk.mta.hu \\ University of Pécs, Institute of Geography, \\ H-7624 Pécs, Ifjúság útja 6., Hungary \\ e-mail: pnorbert@gamma.ttk.pte.hu
}

The authors first review the investigations into the history of the lost mausoleum (türbe) and the surrounding complex of Sultan Süleyman who died during the siege of Szigetvár on September 7, 1566. Then they narrate the establishment in 2012 (reshaped in 2015) of a research group which, by developing a new concept and using interdisciplinary research methods (including landscape reconstruction), found the remnants (foundations) of the türbe on the top of the Turbék-Zsibót vineyard hill in autumn 2015, then, during the rounds of excavation in 2016-2017, the foundations of the adjacent mosque and dervish convent as well as the traces of a fourth building. Regarding the date of the construction of the complex, the authors are of the opinion that the main buildings must have been built around 1575. Finally, they enlarge on the reception of the findings and the potential the site offers for touristic and regional development.

Key words: Süleyman the Magnificent, Ottoman Empire, Szigetvár, türbe, pilgrimage town, geoarchaeology, multidisciplinary studies, regional development.

Sultan Süleyman was the tenth ruler of the House of Osman. He ascended to the throne on October 1, 1520 and died on Hungarian soil, in Szigetvár, on September 7, 1566. Süleyman was one of the Ottoman Empire's greatest conquerors and its last warrior sultan. He participated in thirteen military campaigns - the first and last of which, in symbolic fashion, he led against the Kingdom of Hungary. Süleyman dreamed throughout the forty-six years of his reign of occupying the capital city of the Habsburgs, Vienna, and taking the Holy Roman Empire under his control. However, he never realised this dream. As a result of the global challenges stemming from the magnitude of the Ottoman Empire, Süleyman had to hold his ground on several fronts, thus making it impossible for him to deploy all of the military power at his disposal against the Habsburgs. He therefore devoted most of his efforts to damage control during the second half of his reign. In 1541, Süleyman occupied Buda and gradually conquered all of the territories necessary to maintain control over the late- 
mediaeval capital of the Kingdom of Hungary. Thus began the so-called siege war period during which the Ottoman-controlled territory - retroactively designated in Hungarian as the hódoltság, i.e., "subjugated parts" - within the Kingdom of Hungary took form. At first (1540-1541) Sultan Süleyman wanted to conquer the eastern part of the kingdom, Transylvania, as well, but abandoned this ambition in the 1550s and instead placed the region under the suzerainty of the vassal prince John Sigismund Szapolyai (1556). In 1547, Süleyman concluded a peace agreement with the Habsburg brothers. This treaty formally recognised the fiction of the sultan's sovereignty throughout the entire Kingdom of Hungary, but in fact acknowledged the control of Ferdinand I of Habsburg over the territory that he had taken into his possession within the realm. The Kingdom of Hungary was thus divided into three dominions, each of which placed the borders of the others under constant open or covert pressure. In the east, John Sigismund and the kings of Hungary (Ferdinand I and, from 1564, Maximilian I) attempted to expand the territories under their authority at the expense of one another. In 1565, John Sigismund had fallen into such a weak position in his struggle against the Habsburgs that Süleyman was forced to send an army to assist him. This is when the sultan got the idea of launching a military campaign aimed at permanently settling the situation in the divided kingdom (Tracy 2013; 2016; Fodor 2015-2016).

Southern Transdanubia and Slavonia gained particular importance among the many theatres of war in the Kingdom of Hungary during these years. Beginning in 1544 , local Ottoman forces captured a succession of fortresses in these regions and within a period of two years had conquered nearly all of Baranya and Tolna counties. Sziget(vár) ("Island Castle") became the centre of the Hungarian defensive network that emerged in Southern Transdanubia at this time, particularly after the fall of Pécs to the Ottomans in 1543. Beginning in the second half of the $1540 \mathrm{~s}$, a zone of defense was established behind Szigetvár that enabled the fortress located in this town to protect Southern Transdanubia from Ottoman expansion. During these years, a modern system of fortifications was built around the fortress, which assumed its unique configuration composed of four distinct parts. The fortress was, in fact, located on an island formed in the dammed up waters of Almás Creek. By the 1550s, Szigetvár had truly "become a main bastion" that along with the similar strongholds of Eger and Gyula attempted to impede the advance of the Ottomans and to preserve the authority of the Hungarian state in lost territories (Szakály 1981). The hajdú irregulars of Szigetvár posed a continual threat to Ottoman soldiers and their civilian supporters in Southern Transdanubia and effectively hindered communications between Ottoman forces in this region and Buda (Varga 2006). The Ottomans could not stabilise their dominion over the central portion of the Kingdom of Hungary without conquering Szigetvár and the other two previously mentioned strongholds. Along with the "rescue" of Transylvania, the capture of the fortresses of Szigetvár, Eger and Gyula thus represented the main objectives that the 72-year-old Sultan Süleyman wished to attain when he decided to personally lead his armies on a military campaign to Hungary in the spring of 1566. This decision was, of course, based on other considerations as well, the most important having been that the sultan wished to quell the increasing 
complaints that he had not left his home base in ten years. That is, he wished to restore his weakened authority by defeating the "Viennese king" just as he had done during his youth (Emecen 2014; Fodor 2016). The sultan's 50,000-man army placed Szigetvár under siege on August 5, 1566 and captured the fortress just over one month later, on September 7. However, Süleyman was unable to take pleasure in this triumph: he died in his ornate tent at around 1:30 a.m. on the latter date. Count Miklós Zrínyi, the commander of the Hungarian forces defending Szigetvár, followed Süleyman in death during a sortie against the besieging Ottomans at around noon on September 7, thus keeping his vow to die as a hero rather than surrender to the enemy (Fodor-Varga 2016).

Grand Vizier Sokollu Mehmed Pasha, with the help of inner servants kept the death of Süleyman secret for 48 days, including the more than one month in which the sultan's body lay buried beneath his tent, in order to maintain the morale of the Ottoman army and to ensure that succession to the throne would take place smoothly (Vatin 2005; 2008; 2017; Emecen 2014; Fodor-Varga 2016). A so-called memorial türbe (meşhed, makam) was subsequently built on the site of the sultan's tent and a temporary burial site, while a mosque, a dervish convent and guard barracks were constructed around it. Certain 17th-century sources also mention the presence of a school, a bath and caravanserai at this location. A small town (kasaba) composed of two districts (mahalle) gradually emerged around this complex, which was enclosed within a palisade that was held under the protection of several dozen sentries. Hungarian troops ransacked the complex during the so-called "winter campaign" of early 1664, but they did not find the golden vessel in which Sultan Süleyman's internal organs were allegedly buried (Berkeszi 1886, p. 255; Takáts 1927, p. 129). The Ottomans rebuilt the devastated town. However, three years after the fall of Szigetvár to Habsburg forces in 1689, an imperial quartermaster, without authorisation, ordered to dismantle the "marble building" of the türbe so that he could sell its valuable lead roof and large gilded finial (Takáts 1927, pp. 129-132). This act initiated the process of the memorial site's destruction. Local residents remembered much about the former "Turkish rampart" (Türkische Schantz) in the 18th century (Kitanics 2014; PapKitanics 2015), though by the 20th century they no longer knew precisely where the pilgrimage place dedicated to the memory of Sultan Süleyman had been located.

Such places were sacred for the Ottomans. Sultans visited the mausoleums of the major saints and their distinguished ancestors upon ascending the throne or before launching military campaigns in order to ask them for spiritual support and blessing for their rule or new martial enterprises (Vatin 1995). Ottoman troops often stopped at Süleyman's türbe in Szigetvár after arriving to Hungary in order to pray and request the sultan's spiritual assistance in future military engagements. Apart from Süleyman, one other sultan had died in battle on foreign soil: Murad I in the first Battle of Kosovo in 1389. A mausoleum was built at the place where Murad fell (though perhaps only during the second half of the 15 th century or even later) and over time, the türbe of this sultan also became a pilgrimage site (Şenyurt 2012; Konuk s. a.; Vatin 2017). The persistence of this tradition is reflected in the fact that in 1911 Sultan Mehmed V Reşad went to the türbe of Murad I in order to deliver a speech intended to 
galvanise the Muslims of the Balkans on the eve of the First Balkan War (Baymak 2012, pp. 128-137; Konuk s. a., pp. 19-21). ${ }^{1}$

Three basic questions must be answered in order to clarify the history surrounding the türbe of Sultan Süleyman: when was it built, where was it built and precisely how did it look? The many researchers who have tried to tackle these problems over the past 100-plus years have come up with very disparate results. Béla Németh made the first attempt to answer these questions in his 1903 book on the history of Szigetvár (Németh 1903). Németh fused historical fact and legend in order to formulate the following four major conclusions - which have remained influential to this day - regarding the türbe of Sultan Süleyman: first, the "marble" mausoleum had been built on the site of the sultan's tent, the current location of the Turbék Catholic pilgrimage church; second, in accordance with local tradition, the sultan had died after being shot alongside the lake not far from the castle where "a linden tree stood" and his internal organs had been taken from there across to Turbék (Pál Esterházy already called this belief into question in his 1664 book Mars Hungaricus; see Esterházy 1989, p. 141); third, based on an illustration in Mars Hungaricus, the türbe and other buildings had stood within a fortress protected on three sides by a moat; and fourth, the "Turkish cemetery"2 located close to Almás Creek had assumed this name, which was still used when Németh wrote his monograph, because bones exhumed from Ottoman graves located around Süleyman's türbe had been reburied there during the construction of a church in honour of the Virgin Mary on the site of the sultan's mausoleum in Turbék. Many other researchers have also subscribed to the notion of continuity between the türbe and the church/chapel. One of these researchers, Pál Hal, initially determined that the "Turkish cemetery", which was thought to be pentagonal, was located on the site of Süleyman's death marked with the letter $F$ on the map that the military engineer Leandro Anguissola drew in 1689. However, as Németh, Hal eventually concluded that the sultan had not died at this location, but that the bones of Turks had been reburied there after having been unearthed during the construction of the church in Turbék (Hal 1939). The archaeologist Valéria Kováts also searched for the türbe at the latter church, though in the course of 1971 excavations found only Ottoman-era building materials that had subsequently been added to the original structure. Kováts found a corner of the türbe during the excavations conducted in 1971

\footnotetext{
${ }^{1}$ See the material on display at the exhibition at the reception building connected to $\mathrm{Mu}-$ rad's türbe, which several members of our research group (Pál Fodor, János Hóvári, Norbert Pap and Máté Kitanics) visited in October 2015. Kosovo represents an emblematic place and cornerstone of national mythology for the Serbs as well. According to the traditional account of Murad's death, a Serbian member of the lesser nobility named Miloš Obilić managed to gain access to the sultan following the Ottoman victory in battle and killed him with his dagger (Takács 2007). Interestingly, and perhaps not incidentally, Obilić served as the model for Gavrilo Princip, whom a lot of people in Serbia do not hold in the least responsible for the outbreak of the First World War (Gaćinović 2014, p. 216).

${ }^{2}$ In 1994, a Hungarian-Turkish Friendship Park was established amid some controversy on the site of this "Turkish cemetery". The construction of a symbolic sepulchral structure in the name of Sultan Süleyman behind two monumental statues served to significantly increase the historical legitimacy of the park.
} 


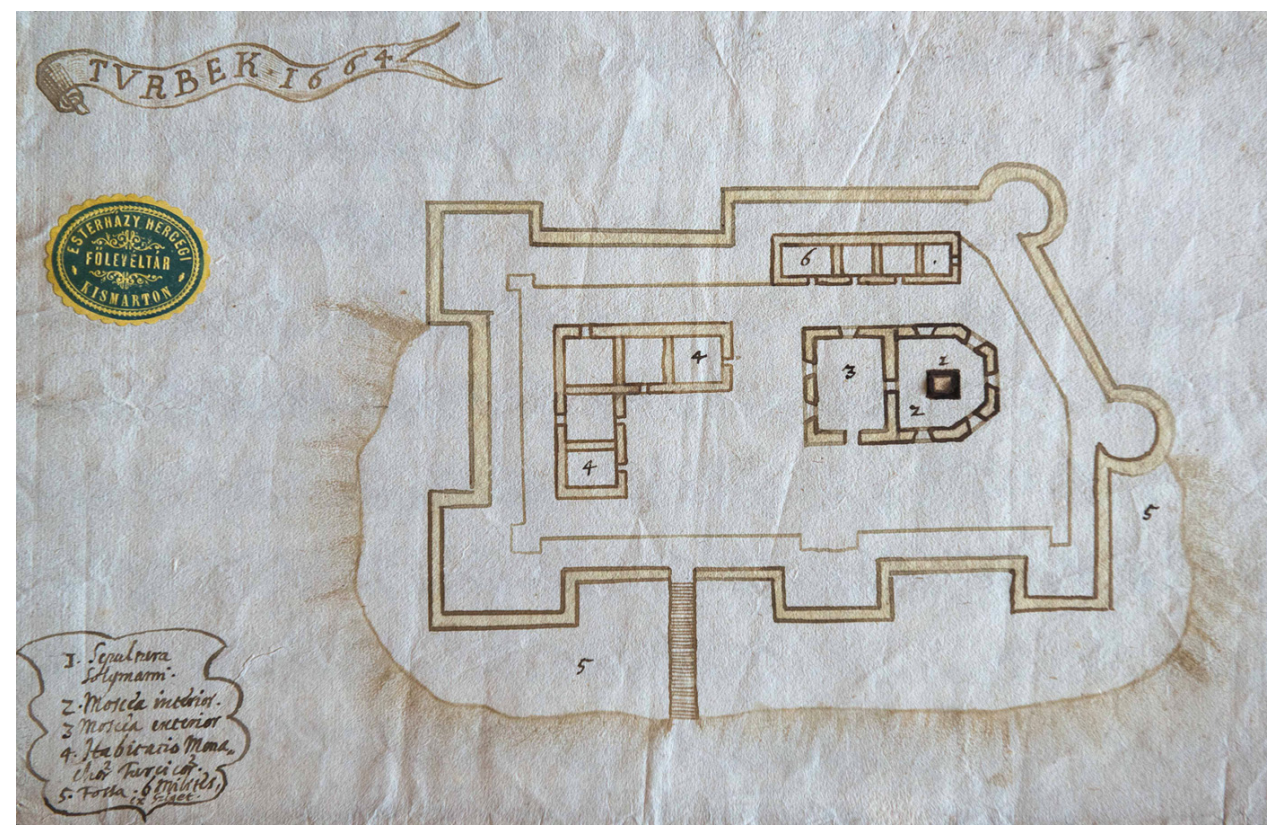

Illustration 1. Pál Esterházy’s sketch plan of Turbék from the year 1664. Photo: Ákos Stiller

and 1972 on the top of the Turbék-Zsibót vineyard hill approximately one kilometre from the church, but clinging to her original hypothesis, she identified it as part of an Ottoman guard-post and covered it back up. The local tradition according to which first a wooden chapel and then the currently existing church were built in honour of the Virgin Mary on the site of the türbe and the mosque following the expulsion of the Turks has served to validate the theory of türbe-chapel continuity. This church located in Turbék became a pilgrimage site symbolising the triumph of Christianity over Islam (Kováts 1963; cf. Gárdonyi 2016, pp. 24-27). It was for this reason that in 1913 the Ottoman government had a bilingual commemorative plaque placed in the wall of the church stating that the heart of Süleyman had been buried there and that it was the former site of the sultan's funerary chapel (Sterner 2016, pp. 47-51).

Contrastingly, based on presumed moats shown on the sketch plan in Pál Esterházy's Mars Hungaricus, another group of researchers has concluded that the türbe and the fortress must have been located at water's edge, most likely along the banks of Almás Creek. In 1965, József Molnár espoused this viewpoint, concluding that Sultan Süleyman's türbe may have been located at the place marked with an $F$ and designated as "Orth wo der Türkische Kaiser Solimanus ist gestorben" on Leandro Anguissola's previously mentioned 1689 map, on the site of the circular building visible in the pentagonal enclosed area just to the east of Almás Creek (Molnár 1965). According to Molnár, certain Turkish sources claim, in conformity with contemporary legend, that the sultan's tent was first erected on the shore of a "lake" and moved 
across to the top of a hill only a couple of days later, and this serves to support this notion. ${ }^{3}$ Molnár rejected the theory of türbe-chapel continuity on the following grounds: "It is inconceivable that the Catholic Church would have chosen to establish a memorial above the mortal remains of a 'pagan' sultan".

Researchers who attempt to determine how the türbe and the surrounding complex/small town looked tend to base their findings on Pál Esterházy's 1664 sketch plan. In a recent comparison of Esterházy's pen-and-ink drawings with the results of archaeological investigations of several Ottoman palisades in Southern Transdanubia (Barcs, Berzencze, etc.) Gyöngyi Kovács (2015) discovered that these drawings depicted some structural details accurately and others inaccurately. Most Ottoman türbes were octagonal in shape, though some were quadrilateral, hexagonal or, primarily in the Balkans, heptagonal. The two türbes that still stand in Hungary - the türbe of İdris Baba in Pécs and the türbe of Gül Baba in Budapest - are octagonal and covered with domes (Sudár 2013). In 2015, Turkish architect Mehmet E. Y1lmaz produced a theoretical reconstruction of both Süleyman's türbe and the surrounding complex based on the above-mentioned factors and similar structures in Asia Minor and the Balkans. According to Y1lmaz, Esterházy's sketch plan suggests that the sultan's türbe was a hexagonal structure and covered with a lead dome and was connected structurally to the mosque (Y1lmaz 2015). The reconstruction that Yilmaz forged with such great expertise well illustrates the fate of a scholar: after working so long and hard to formulate the most likely hypothesis based on the consideration of primary sources and all existing parallels, the results of other research refuted the Turkish architect's conclusions virtually just a few days after they were published. However, before examining the latter episode, we will turn our attention to the question of when the türbe of Sultan Süleyman was built.

Significant advance was achieved in this regard several years ago. This progress could have been made earlier if researchers had not gradually forgotten about the conclusions that one of our colleagues published on this subject many years ago (Ágoston 1991, pp. 197-198). It has in this way become customary to cite an article and sources that the French Ottomanist Nicolas Vatin published in 2005 as more or less representing an answer to the question of when Süleyman's türbe was constructed (Vatin 2005; 2008). The most important sources - decrees of the Ottoman imperial council - state that in the early autumn of 1573 only a "memorial garden" was located on the site where Sultan Süleyman's tent had stood, while in March of 1576 both the türbe and almost the entire surrounding complex had been completed (Vatin 2005; 2008, pp. 67-72; Y1lmaz 2015, pp. 166-171, 175-181). Since the commands specify that the mosque and the dervish convent should be "newly built", one may conclude that the main buildings of the small town were likely raised only during the year 1575 and that, contrary to subsequent belief, Murad III (1574-1595) ordered their construction rather than Süleyman's son, Selim II (1574-1595). However, several contradictions exist among the various sources that are difficult to resolve at present.

${ }^{3}$ However, Feridun Emecen (2014) asserted that contemporary Ottoman-Turkish sources cannot be unambiguously interpreted in this way. We believe that the question requires further investigation. 
Grand Vizier Sokollu Mehmed Pasha's endowment deed (vakıfname, vakfiye) bearing the date April 13-22, 1574 (evahir-i zilhicce li-sene 981) states that the pasha had had a mosque (cami) built on the sultan's burial site "in the palisade that has become known as the palisade of the türbe" and had ordered personnel to serve at this location. Moreover, the document claims the entire complex to be the work of Sokollu Mehmed Pasha. ${ }^{4}$ In contrast to this statement, the mentioned decrees of the imperial council and the land survey register of the sub-province of Sigetvar of 1579 clearly state that the complex was erected upon the orders of the ruler and that the whole site and the inhabited and deserted villages attached to it were part of the ruler's pious foundation. Another contradiction is that if the date of the vakıfname is correct, then a mosque should have stood at this place already in the spring of 1574 , whereas one of the sultan's decrees explicitly states that the place of worship located next to Süleyman's türbe was converted into a "Friday mosque" (djami) - one at which Friday sermons (hutbe) were held - only in March 1576. In our opinion, these contradictions stem from the possible misdating of Sokollu Mehmed Pasha's vakıfname to April 1574. Evidence suggests that only later copies of this lengthy document listing the pious foundations that Sokollu Mehmed Pasha had established throughout the empire (one version according to types of buildings, another according to geographical location, see Necipoğlu 2005, pp. 346 ff., 543, notes 347-348) have survived. ${ }^{5}$ We have every reason to presume that the year 1574 which appears at the end of the endowment deed copied in the 19th century pertains only to the year in which one of the listed foundations was established and not to the year in which all of the them were established, as researchers have surmised (on this question in detail, see Fodor forthcoming). The testimony of the divan's decrees and of the survey register of the sancak of Sigetvar as well as their dates, however, should be considered unquestionable evidence. Based on the available documents, one thing is certain, namely that the vineyard-hill memorial and pilgrimage site existed already in early 1576 and was located where Süleyman's tent had been erected in 1566 and where the sultan's body had been temporarily buried. ${ }^{6}$ To complicate the matter further, two Habsburg spy reports

${ }^{4}$ Ankara, T. C. Başbakanlık Vakıflar Genel Müdürlüğü Arşivi, Defter No. 572, p. 55. Cf. Y1lmaz 2015, pp. 98-99, 172-173 (with incorrect date).

${ }^{5}$ For example, the Ankara copy cited in the previous footnote is a 19th-century copy, while the Istanbul copy was undoubtedly produced after Sokollu Mehmed Pasha's death in 1579. The parts of the documents pertaining to the Szigetvár türbe do not appear in the latter copy (see Gökbilgin 1952/2007, pp. 509-512), which serves to strengthen the suspicion that the Ankara version contains a later interpolation. Nevertheless, the problem can only be resolved in a satisfactory manner through careful comparison of all of the existing versions of the endowment deed, an enterprise that we plan to undertake in the near future.

${ }^{6}$ The unrealistic notion has recently emerged among certain Turkish researchers (based on their misinterpretation of sultanic decrees) that the türbe and mosque were located within the fortress of Szigetvár. We would draw their attention to the following key sentence that appears in Sokollu Mehmed Pasha's vaklfname: "One of the mosques [among the seven noble mosques that Sokollu had built] was that which was constructed outside the fortress named Szigetvár on the place where the noble body of the departed Sultan Süleyman was temporarily interred (biri dahi Sigetvar nam kalenin haricinde merhum Sultan Süleyman'in cesed-i şerifleri emanet konulan mevzide bina olunan camidir).” Ankara, Vakıflar Genel Müdürlüğü Arşivi, Defter No. 572, p. 28. Cf. Hancz 2014, 
(from March 21, 1567) state that the Ottoman governors of the region were ordered as early as 1567 to build either a memorial place (ain gedachtnus), or a hospital, or a bath (ain spittall oder bad(?)haus) near Szigetvár at the place where the "former emperor died". 7 But as the second informant notes, these news may have served to conceal the military preparations against Habsburg territories. At the same time, these "rumors" may testify to the Ottoman leadership having considered the erection of some kind of a memorial place immediately after the death of the sultan.

Turning now to the questions of the location and external appearance of Süleyman's türbe and the surrounding structures, one can state that the situation has become much clearer in this regard over the past five years primarily as a result of two interconnected research programmes based on entirely new research approaches. The Türk İşbirliği ve Koordinasyon Ajans1/Turkish Co-operation and Co-ordination Agency (TIKA) provided financial support for the initial phase of research through an agreement concluded with the Szigetvár local council in late 2012 (and for which Hungary's ambassador to Turkey at that time, János Hóvári, deserves immense credit). This agreement called for University of Pécs geographer-historian Norbert Pap to organise a research group and develop a concept based on a new type of approach. The agreement stipulated that, if possible, the research group should finish its work by September 2016 (Pap 2014). TIKA provided financial support for the research from the start of the project until the 2016 deadline for its completion. The objectives of this research were to first determine the possible locations of Sultan Süleyman's türbe, then to narrow these possibilities down to one location and, finally, to find and unearth the structure.

During the very first year of the project, deepening co-operation developed between the above research group and the Research Centre for the Humanities of the Hungarian Academy of Sciences (RCH HAS). In early 2015, the research group and the RCH HAS submitted a joint application for funding to the Hungarian Scientific Research Fund (the biggest national research foundation in Hungary) and were granted considerable support for a period of three years in order to complete the project entitled The Political, Military, and Religious Role of Szigetvár and Turbék in the Rivalry of the Ottoman and Habsburg Empires and in the Ottoman-Turkish Regime in Hungary - Facts and Memory. Pál Fodor and Norbert Pap have directed the research connected to this project since September 1, 2015. This research had previously been conducted along several trajectories, and from that time it expanded even further: environmental-history and battlefield-archaeology investigations were carried out in order to supplement geophysical, archaeological, historical-geographical, historical and memory politics research. In addition to the University of Pécs, the Institute of History and the Institute of Archaeology at the RCH HAS, the National University of Public Service, the Eötvös Loránd University, the University of Szeged and

p. 67 (with minor errors). The previously mentioned imperial decrees stated that the türbe was built "in the vicinity/opposite to Szigetvár" (Sigetvar kurbünde/mukabelesinde).

${ }^{7}$ Graz, Steiermärkisches Landesarchiv, Landschaftliches Archiv, Antiquum XIV., Militaria Schuber 34 (1567), ADB 4289 and ADB 4290. We express our gratitude to Szabolcs Varga for calling our attention to these documents. 
several specialists from Turkey have also participated. The following section of this study will summarise the combined results of the two projects. ${ }^{8}$

The research phase that began in 2013 focused on the survey of the geographical environment. The construction of the türbe and the pilgrimages to the site took place during the so-called "Little Ice Age". The notion - connected primarily to Norbert Pap - therefore emerged to reconstruct the geographical and environmental conditions that prevailed during this period and to compare this reconstruction to these factors in the primary sources (Pap 2014b). This undertaking was based on the premise that the türbe and the adjacent buildings had been located in an area which might have been cooler and damper than today and had different vegetation. We concentrated our efforts on determining the primary characteristics of the geographical environment through landscape reconstruction and the examination of the sources in the context of the results of this investigation. Finally, Péter Gyenizse and Zita Bognár prepared the geographic information system (Gyenizse-Bognár 2014).

The two previously mentioned sites - the Turbék church and the "Turkish cemetery", i.e., the Hungarian-Turkish Friendship Park - both stood on flat, soggy ground. The landscape reconstruction survey revealed that the waters of Almás Creek periodically inundated the adjacent terrain, which thus formed a floodplain that would have been an unsuitable location for a permanent settlement. Indeed, there is no archaeological evidence that such a settlement existed at this location during the period in question and no Ottoman-era objects have been unearthed there. ${ }^{9}$ The area around

${ }^{8}$ In fact, the origin of these projects reach back to 2009, when Erika Hancz and the Turkish researcher Fatih Elçil conducted probe research in the garden of the Turbék church and geophysical testing in both the church garden and within the church itself. Hancz and Elçil determined that the Turbék church could not have been the gravesite of Sultan Süleyman. Not only did their excavation and testing fail to uncover evidence of the imposing buildings, ramparts, trenches and palisade to which numerous sources referred, but they found no archaeological artifacts that reflected the presence of enduring settlement and everyday life during the period in question. Those objects that Hancz and Elçil found at the location stemmed from the 18th century or later. This also applies to coins found in the course of systematic research and excavation as well. The archaeological excavation done within the framework of the research programme took place with the support and financing of the National Office of Cultural Heritage. University of Pécs professor Dr. Zsolt Visy, Istanbul University departmental chairman and professor Dr. Ara Altun and Istanbul University docent and professor Dr. Mehmet Baha Tanman participated in the programme as consultants. Dr. László Gere of the National Office of Cultural Heritage also followed the progress of the research. Cf. Kitanics - Hancz-Tóth - Pap 2017.

${ }^{9}$ Pál Hal (1939) published an account of the first excavation at this site which is associated with a local resident named Béla Salamon. The archaeologist Valéria Kovács reported the results of her investigation of the "Turkish cemetery" in an excavation documentation published in 1971 (Kovács 1971). Finally, Kovács examined the grounds of the Hungarian-Turkish Friendship Park at the time of its establishment in 1994, but found nothing to suggest that the Turks had been present at that location. In 2013, our research group conducted several inspections of the territory and examined aerial photographs of the site as well - but these produced no results. We do not know if the name "Turkish cemetery" signifies that the clearly discernable tumulus located there had something to do with an Ottoman-era burial ground or if popular memory simply traced its origin to this period without reflection as it did in so many other places with regard to things deemed to be "old". Only further research from our research group can provide an answer to this question (for more detail regarding the connection of "oldness" and the "Turkish era", see Kováts 1962; 1963; Rácz 1995). 
the church is also wet and would have therefore been an inappropriate site for settlement as well. Moreover, the results of the survey indicated that the fortress of Szigetvár was not even visible from this location and was built in such a deep-lying area that it could not have served as a command post. The church is located more than 600 metres from the vineyard hill and the gardens, thus making it incompatible with the claim in the sources that it was surrounded by vineyards and gardens. Furthermore, no physical evidence has been discovered at either location that would serve to suggest that they had once been the site of the big buildings, connected defensive fortifications, permanent settlement or frequent pilgrimage mentioned in the sources.

The results of the landscape reconstruction survey and evidence from 17thcentury maps eventually led us to the top of the Turbék-Zsibót vineyard hill, a location that was also compatible with the most credible 16th-century sources which placed Sultan Süleyman's camp on a nearby elevation referred to as either Semlék or Szemlö hill (Pap et al. 2015). The maps, which were produced in the 1680s and 1690s, show a settlement located closer to the stream running alongside Zsibót then to Almás Creek. According to the legends on these maps, this settlement was of medium size or importance, while texts appearing on the maps state that Süleyman either died on the site of this settlement or his mausoleum was located there. Máté Kitanics unearthed 15 new 18th-century Latin, German and Hungarian written sources which served as conclusive evidence that this localisation was correct (Kitanics 2014; cf. Gözsy 2016). According to the geographical information contained in these sources, the named location was situated to the east of the fortress of Szigetvár at a distance of a quarter Hungarian mile (that is, between four and five kilometres) or one hour's walk on a hilly place next to the vineyards and the corn fields. These sources refer to the Turbék fortress and its buildings as the "Turkish Rampart" (Tükische Schantz in the German-language sources) and assert that the chapel-shaped türbe, the Halveti dervish convent (tekke) and the "grand mosque" were located within this stronghold. According to the sources, the head of the order lived with the dervishes in the convent "enclosed" within the palisade. The sources make a palpable distinction between the "Rampart" and the interior of the fortress, thus one may presume that the Ottomans lived in between the "Rampart" surrounding and protecting the fortress and the castrum, while the Christians lived beyond the "Rampart". Following the expulsion of the Ottomans, the fortress and the connected land were given to the Jesuit Order which consecrated the türbe to the Helping Virgin Mary. However, the Jesuits did not imbue the building with a true sacred function, holding religious services at the former mosque standing next to the convent. As previously mentioned, the consecrated chapel, that is, the türbe, and likely the mosque were dismantled in the years $1692-$ 1693 in order to sell the materials from which they had been constructed (Takáts 1927, pp. 129-132).

Following our field surveys, we announced at a 2013 conference that we would conduct further investigation in the area of the Ottoman-era ruins which we considered to be the possible site of the former pilgrimage settlement. Gardens, vineyards and - on one side - plowland had surrounded these ruins for centuries. This site is located 4.2 kilometres to the northeast of the fortress and its surface is covered with 
evidence of Ottoman life. These include fragments of luxury items suggesting that the people who lived here during the Ottoman era were quite affluent. This location affords a good view over the town and is situated at the junction of roads proceeding toward the east (in the direction of Pécs) and the north (in the direction of Kaposvár) next to the Szilvási Inn, which has stood at this intersection for several hundred years. It is an ideal place for an encampment and command post as well as for the construction of buildings. The presence of an expansive field of Ottoman-era ruins speaks in favour of this site in comparison to the other two locations. In 2013, we cautiously stated that the türbe was likely located in the area between the Szilvási Inn and the Helping Virgin Mary Church and totally excluded the possibility that it might be found along the banks of the Almás Creek. Only the location of the big buildings, the fortifications and the defensive trenches remained undetermined. In late 2014 and early 2015, we conducted a series of instrumental tests at the church and its broad surroundings that revealed no evidence of the foundations of big buildings or the vestiges of fortifications and trenches (Kitanics-Hancz-Tóth-Pap 2017). However, geophysical investigations carried out at the site on the vineyard hill uncovered the presence of several fairly large buildings oriented toward the southeast that were compatible with those described in the sources, and also some traces of a possible fortification. One of the buildings had a square-shaped foundation and was oriented with exceptional accuracy in the direction of Mecca. The positioning of the buildings corresponded to those shown on the 1664 sketch plan (dervish convent, mosque, türbe, military barracks and remnants of the fortress). The trench-system surrounding the buildings was precisely identified, first through a remote sensing photogrammetric examination (conducted with a drone) and then using LIDAR. In 2013, we discovered traces over a relatively large area of an Ottoman settlement with big buildings at its centre that corresponded to the attributes of the small town of Turbék that appear in the sources. Moreover, according to popular tradition, the sultan established his encampment here. As mentioned, Christian sources also indicate that the camp of the Turkish sultan was "up on the hill" referred to as either Szemlö or Semlék hill (Ruzsás-Angyal 1971, p. 65; Istvánffy 2003, pp. 411-412; Kitanics 2014, p. 101). Local residents, though they no longer use these names in reference to this location, still produce "Szemlo" Hill" wine. These residents assert that "Turkish ruins" once stood at this site and they have reported the discovery of Ottoman-era archaeological remains on several occasions.

Following the preliminary investigations described above, archaeological research began on October 5, 2015. We knew not only what we were seeking, but - on the basis of the ground penetrating radar analysis - also where to look for it. In the course of the Erika Hancz-led excavation that lasted until November 7, we located and unearthed the remnants of the wall of the türbe. The walls of the square building erected during the Ottoman period were made of stone and brick. The central space of the türbe measured 7.9 metres by 7.9 metres and could be approached from the northwest via a three-section porch. No traces of a minaret or a prayer niche (mihrab) were found. The building was covered with flagstone. A two-metre-deep robber pit that likely plunderers dug at the end of the 17 th century lies yawning in the central 


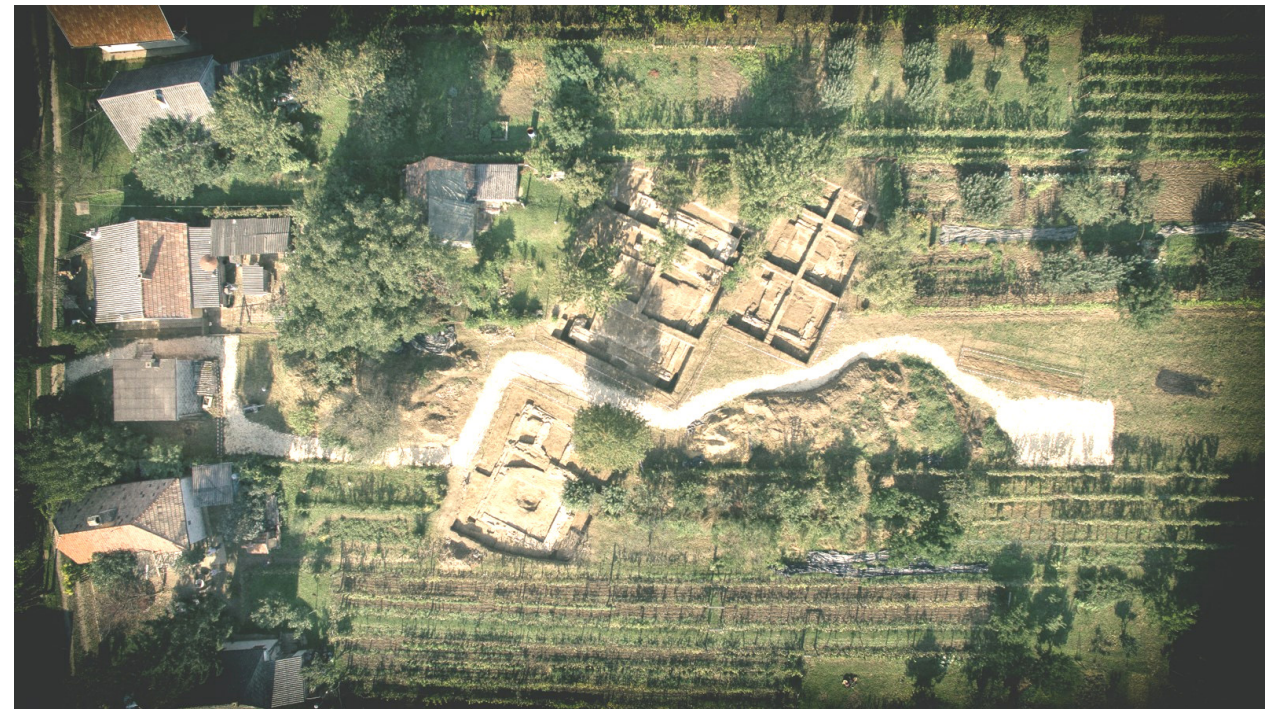

Illustration 2. Aerial photograph of the excavation

Detail of the mosque, the türbe and the dervish convent. Photo: András Szamosi

hall of the türbe. Decorative elements found amid the ruins of the building are akin to those on Sultan Süleyman's türbe in Istanbul. These 2015 excavations and the other testing and analyses all suggested that this building was Süleyman's türbe. Further investigation was nevertheless required in order for us to be able to state this with 100 -percent certainty. Specifically, the ruins of nearby buildings needed to be excavated. This is why in the spring of 2016 we began to unearth the remnants of the presumed mosque and dervish convent.

However, before this, in early December 2015, we conducted further geophysical surveys in order to gain an even more exact image of the floor plans and the positioning of the buildings (convent, mosque and türbe). Radar analysis promisingly revealed that the buildings were oriented precisely according to those appearing on a newly surfaced (and not yet published or authenticated) 1689 depiction of them. ${ }^{10}$ A written source from the period also indicates that the orientation of the building foundations that we had unearthed were identical to those of the buildings constructed around Süleyman's türbe. In 1693, a witness stated before a Habsburg Imperial War Council investigation committee that among the buildings at the location in question

${ }^{10}$ This drawing (part of a larger sketch) is in the possession of a German private individual who offered to sell it to our research group in 2013. The orientation of buildings shown on the detail of the sketch that he presented to us (for which we received a legend as well) was nearly identical to that of the buildings that we had excavated (dervish convent, mosque and türbe). The owner of the document maintains that the same Leandro Anguissola who drew the map of the castle and its vicinity at the time of the 1689 blockade of the Ottoman-held stronghold produced this drawing as well - although we do not regard this claim to be completely verified. The emergence of this drawing shows that there is still work to be done in the search for further visual sources. 
which had been consecrated as chapels, religious services had never been held at Süleyman's türbe, although even Bishop of Pécs Mátyás Ignác Radonay had celebrated mass at the former mosque that lay in the direction of the dervish convent (Takáts 1927). Thus the radar analysis, the newly surfaced sketch and the above testimony all indicated that the sequence of the three buildings along a northwest-to-southeast axis was first convent, then mosque and finally türbe. A new wing was apparently added to the convent in 1664, while the mosque and the türbe - as the excavations revealed were built about six metres apart from one another and were therefore not connected. Taken together, this evidence provided further confirmation that we had found Sultan Süleyman's türbe, and the results of further archaeological excavations provided definitive proof of this. (Besides, the fact that the three buildings could be found at the same location as well as their position in relation to one another served in itself to corroborate the hypothesis that Süleyman's mausoleum had once stood at the site, since we know about the existence of no other settlement of such composition in Ottoman Hungary.) After having come to this conclusion, the main question was the degree to which archaeological research either confirms or refutes the functions of the buildings specified in written sources. In late May 2016, the corner walls of the mosque were found during the first days of the subsequent round of excavations. Following this, we unearthed the entire foundation of the mosque as well as the remnants of walls from some of the cells of the convent. The foundations of a minaret were also identified. In summer 2017, during the new round of excavation, the foundations of the convent were fully uncovered. Moreover, the remnants of a separate building became visible to the south of the dervish convent. According to our current hypothesis, this building may have been a guest house that formed an integral functional unit with the dervish convent. However, we must conduct further investigation to test this hypothesis. Thus, overall, everything has so far proceeded according to our expectations.

Finally, we will examine the reception of our findings. It rarely occurs in the lives of scholars in the humanities that their research results elicit such a strong reaction as did ours. Following a TIKA-sponsored press conference on December 9, 2015, several of the world's most influential newspapers reported upon the discovery of Süleyman's mausoleum. This interest stemmed from the approach of the 450th anniversary of the 1566 siege of Szigetvár and the death of Sultan Süleyman. Numerous television stations, including German public broadcaster ZDF (which made a film with our participation that was shown on April 17, 2016), Croatian public television (also with our assistance), the Travel Channel and a Turkish station, made documentary films about the anniversary. The interest shown toward our work throughout the world suggests that its importance may extend beyond the academic sphere. Furthermore, its social and economic effects may have a favourable impact on the lives and economic circumstances of those who live in the vicinity of Szigetvár. As we wrote in our application for funding from the National Research, Development and Innovation Office: "If the research work is completed successfully and we are able to uncover and reconstruct the former Ottoman religious centre (the tomb of Süleyman) as planned, it will not only be beneficial to historians and archaeologists, etc., but it will also serve as the foundation of touristic and regional development that Szigetvár and 
its vicinity has needed for a long time. The international benefits of the research are also indisputable, since it may contribute to improving ... the international relations with the affected countries (of different cultures) which, in a tense international environment, is more needed than ever before."

The primary social objective of the research formulated in 2015 will apparently be realised as a result of its significant scientific results. The government of Hungary determined the destiny of the excavation site in June 2017, when it ordered that the affected territory be placed under state ownership and provided the financial resources needed to complete the required research in the area of the mausoleum and to formulate plans regarding its touristic utilisation. ${ }^{11}$ At the same time, it will be necessary to continue scientific work at the site of the mausoleum even after the relevant government objectives have been attained. We must carry out further investigation in order to enhance our knowledge of the structure of the small town having existed to the south of the building complex that has so far been unearthed and its attendant fortifications, to deepen our understanding of the lives of the residents of this settlement and to uncover the many other secrets that this site holds.

\section{References}

Ágoston, Gábor (1991): Muslim Cultural Enclaves in Hungary under Ottoman Rule. AOH Vol. 44, Nos 2-3, pp. 181-204.

Ágoston, Gábor (1993): Muszlim hitélet és müvelődés a Dunántúlon a 16-17. században [Muslim religious life and culture in Transdanubia in the 16th-17th century]. In: Szita, László (ed.): Tanulmányok a török hódoltság és a felszabaditó háborúk történetéböl. A szigetvári történész konferencia elöadásai a város és a vár felszabaditásának 300. évfordulóján (1989) [Studies on the history of the Ottoman rule in Hungary and of the liberation wars: Proceedings of the conference held in Szigetvár on the occasion of the 300th anniversary of the liberation of the town and the fortress]. Pécs, Baranya Megyei Levéltár, pp. 277-292.

Anguissola, Leandro (1689): Abriss von der Stadt und Vestung Sigeth. Kriegsarchiv, Feldakten, Wien 117 (Fasc. 167).

Baymak, Osman (2012): Sultan Murad Hüdavendigar ve Birinci Kosova Savaşı. Priştine, Bay Yayınları, $160 \mathrm{pp}$.

Berkeszi, István (1886): Gróf Zrínyi Miklós horvát bán téli hadjárata 1663-4-ben [The winter campaign of the Croatian ban Miklós Zrínyi in 1663-1664]. Századok Vol. 20, pp. 253259.

Emecen, Feridun (2014): Kānûni Sultan Süleyman'ın Macaristan'daki Türbesine Dair Görüşler. In: Ergiydiren, Özcan - Aren, Kemal Y. - Yüksel, I. Aydın (eds): Ekrem Hakkı Ayverdi. 30. Yll Hâtıra Kitabı. İstanbul, İstanbul Fetih Cemiyeti (İstanbul Fetih Cemiyeti, 114), pp. 71-86.

Esterházy, Pál (1989): Mars Hungaricus. Prepared for the press ... and translated by ... Emma Iványi. Introduced and edited by ... Gábor Hausner. Budapest, Zrínyi Kiadó, 562 pp. (ZrínyiKönyvtár III).

${ }^{11}$ Government Resolution 1427/2017 (VI. 29). 
Fodor, Pál (2015-2016): The Unbearable Weight of Empire: The Ottomans in Central Europe A Failed Attempt at Universal Monarchy (1390-1566). Budapest, Research Centre for the Humanities, Hungarian Academy of Sciences, 175 and 176 pp.

Fodor, Pál (2016): Szigetvár 1566. évi ostroma: az előzményektől a következményekig [The siege of Szigetvár in 1566: from antecedents to consequences]. Magyar Tudomány Vol. 177, No. 9, pp. 1041-1047.

Fodor, Pál (forthcoming): Sultan Süleyman'ın Ölümü ve Sigetvar'daki Türbesinin Kuruluşu Meselesi.

Fodor, Pál - Varga, Szabolcs (2016): Zrínyi Miklós és Szulejmán halála [Miklós Zrínyi and Süleyman's death]. Történelmi Szemle Vol. 58, No. 2, pp. 181-201.

Gaćinović, Radoslav (2014): Mlada Bosna [Young Bosnia]. Beograd, Medija centar Odbrana, 595 pp.

Gárdonyi, Máté (2016): A turbéki kegyhely kialakulása [The formation of the shrine at Turbék]. In: Varga, Szabolcs (ed.): Szüz Mária segítségével. A turbéki Mária-kegyhely története [With the help of Virgin Mary: a history of the shrine to Virgin Mary at Turbék]. Budapest, MTA Bölcsészettudományi Kutatóközpont, pp. 15-27.

Gökbilgin, M. Tayyib (1952/2007): XV. ve XVI. Asırlarda Edirne ve Paşa Livası, Vakıflar - Mülkler-Mukataalar. İstanbul, İşaret Yayınları, $631+301$ pp.

Gőzsy, Zoltán (2016): Baranya és Tolna vármegye plébániáinak összeirása 1753-1757 [The survey of the parishes in Baranya and Tolna counties in 1753-1757]. Pécs, Pécsi Püspöki Hittudományi Föiskola, 409 pp. (Seria Historicae Dioecesis Quinqueecclesiensis XIV).

Gyenizse, Péter-Bognár, Zita (2014): Szigetvár és környéke 16-17. századi tájrekonstrukciója kartográfiai és geoinformatikai módszerekkel/Sigetvar ve Çevresinin Haritacılık ve Jeoenformasyon Yöntemleriyle 16-17. Yüzyıl Peyzaj Rekonstrüksiyonu. In: Pap, Norbert (ed.): Szülejmán szultán emlékezete Szigetváron/Kanuni Sultan Süleyman'ın Sigetvar'daki Hattrası. Pécs, PTE Kelet-Mediterrán és Balkán Tanulmányok Központja (Mediterrán és Balkán Fórum Vol. VIII - Special Issue), pp. 73-90.

Hal, Pál (1939): Szigetvár 1688 és 1689-ben: Szigetvár török uralom alól való felszabadulásának 250. évfordulója alkalmából [Szigetvár in 1688-1689 - on the occasion of the 250th anniversary of its liberation from the Turkish rule]. Szigetvár, Gróf Andrássy Mihály, 20 pp.

Hancz, Erika (2014): Nagy Szülejmán szultán Szigetvár környéki sátorhelye, halála és síremléke az oszmán írott forrásokban/Osmanlı Kaynaklarına Göre Kanuni Sultan Süleyman'ın Sigetvar'daki Otağ Yeri, Ölümü ve Türbesi. In: Pap, Norbert (ed.): Szülejmán szultán emlékezete Szigetváron/Kanuni Sultan Süleyman'in Sigetvar'daki Hatırası. Pécs, PTE Kelet-Mediterrán és Balkán Tanulmányok Központja (Mediterrán és Balkán Fórum Vol. VIII - Special Issue), pp. 55-71.

Hancz, Erika - Fatih, Elçil (2012): Excavations and Field Research in Sigetvar in 2009-2011: Focusing on Ottoman-Turkish Remains. International Review of Turkish Studies, Special issue on Hungarian-Turkish Relations Vol. 2, No. 4, pp. 74-96.

Hancz, Erika-Pap, Norbert-Varga, Szabolcs-Kitanics, Máté (2015): Szigetvár 1566. Pécs-Szigetvár, Publikon, 158 pp.

Istvánffy, Miklós (2003): Istvánffy Miklós magyarok dolgairól írt históriája. Tállyai Pál XVII. századi forditásában [Nicolaus Istvánffy's history on the matters of the Hungarians, in the 17th-century translation of Pál Tállyai]. Books I/2. Chapters 13-24. Edited by Péter Benits. Budapest, Balassi Kiadó, 503 pp.

Kitanics, Máté (2014): Szigetvár-Turbék: A szultán temetkezési helye a 17-18. századi magyar, német és latin források tükrében/Sigetvar-Turbék: 17.-18. Yüzy1llara Ait Macarca, Almanca ve Latince Kaynaklar Temelinde Kanuni Sultan Süleyman'ın Mezarının Oluşturul- 
duğu Bölge. In: Pap, Norbert (ed.): Szülejmán szultán emlékezete Szigetváron/Kanuni Sultan Süleyman ’n Sigetvar'daki Hatırast. Pécs, PTE Kelet-Mediterrán és Balkán Tanulmányok Központja (Mediterrán és Balkán Fórum Vol. VIII - Special Issue), pp. 91-109.

Kitanics, Máté-Hancz, Erika - Tóth, Tamás - Pap, Norbert (2017): A turbéki kegytemplom török elözményének kérdése [The problem of Ottoman antecedents to the shrine of Turbék]. Történelmi Szemle Vol. 59, No. 1, pp. 1-18.

Konuk, Neval (s. a.): Kosova Sultan Murad Hüdavendigâr Türbesi'nin Tarihçesi. In: İbrahimgil, Mehmet Z. - Konuk, Neval (eds): Kosova Sultan Murad Hüdavendigâr Türbesi Restorasyonu/Restaurimi $i$ Tyrbes së Sulltan Murad Hüdavendigaar'it/The Restoration of Sultan Murad Tomb. Ankara, Türkiye Diyanet Vakfi, pp. 13-22.

Kovács, Gyöngyi (2015): Oszmán erődítmények a Dél-Dunántúlon. Gondolatok Szigetvár-Turbék régészeti kutatása előtt [Ottoman fortifications in Southern Transdanubia: Some thoughts on the archaeological research of Szigetvár-Turbék]. Mediterrán és Balkán Fórum Vol. 9, No. 2, pp. 20-33.

Kováts, Valéria (1962): Szigetvári történeti néphagyományok [Historical folk traditions in Szigetvár]. In: Füzes, Endre - Horvát, A. Olivér - Szabó, Gyula (eds): Janus Pannonius Múzeum Évkönyve 1961. Pécs, Janus Pannonius Múzeum, pp. 129-138.

Kováts, Valéria (1963): Szigetvári történeti néphagyományok [Historical folk traditions in Szigetvár]. In: Papp, László (ed.): Janus Pannonius Múzeum Évkönyve 1962. Pécs, Janus Pannonius Múzeum, pp. 249-285.

Kováts, Valéria (1971): Turbék Excavation Report, 1971. Janus Pannonius Múzeum Régészeti Adattár, No. 1638.83.

Kováts, Valéria (1973): Szigetvár-Turbék szőlőhegy [The vineyard hill of Szigetvár-Turbék]. Régészeti füzetek I. Ser. I, No. 26, entry 194, p. 113.

Molnár, József (1965): Szulejmán szultán síremléke Turbéken [The mausoleum of Sultan Süleyman in Turbék]. Müvészettörténeti Értesitö Vol. 14, No. 1, pp. 64-66.

Necipoğlu, Gülru (2005): The Age of Sinan. Architectural Culture in the Ottoman Empire. London, Reaktion Books, 592 pp.

Németh, Béla (1903): Szigetvár története [The history of Szigetvár]. Pécs, Pécsi Irodalmi és Könyvnyomdai Részvénytársaság (Reprint: 2011, Budapest, Históriaantik), 389 pp.

Pap, Norbert (ed.) (2014a): Szülejmán szultán emlékezete Szigetváron/Kanuni Sultan Süleyman ’n Sigetvar'daki Hatırası. Pécs, PTE Kelet-Mediterrán és Balkán Tanulmányok Központja, 135 pp. (Mediterrán és Balkán Fórum Vol. VIII - Special Issue).

Pap, Norbert (2014b): A szigetvári Szülejmán-kutatás keretei, a 2013-as év fontosabb eredményei/Sigetvar'da Kanuni Sultan Süleyman Hakkında Yapılan Araştırmaların Ana Noktaları ve 2013 Y1lı Sonuçları. In: Pap, N. (ed.): Szülejmán szultán emlékezete Szigetváron/Kanuni Sultan Süleyman'in Sigetvar'daki Hatırası. Pécs, PTE Kelet-Mediterrán és Balkán Tanulmányok Központja (Mediterrán és Balkán Fórum Vol. VIII - Special Issue), pp. 23-36.

Pap Norbert (2017): Iszlám versus kereszténység - szimbolikus térfoglalás Szigetváron [Islam vs. Christianity: symbolic expansion in Szigetvár]. In: Pap-Fodor (eds), pp. 205-242.

Pap, Norbert-Fodor, Pál (eds) (2017): Szulejmán szultán Szigetváron: A szigetvári kutatások 20132016 között [Süleyman in Szigetvár: The Szigetvár research between 2013 and 2016]. Pécs, Pannon Castrum Kft., 299 pp.

Pap, Norbert-Kitanics, Máté (2015): Nagy Szulejmán szultán szigetvári türbéjének kutatása (1903-2015) [Research on the türbe of Süleyman the Magnificent in Szigetvár, 19032015]. Mediterrán és Balkán Fórum Vol. 9, No. 2, pp. 2-19.

Pap, Norbert-Kitanics, Máté-Gyenizse, Péter-Hancz, Erika-Bognár, Zita-Tóth, Tamás-Hámori, Zoltán (2015): Finding the Tomb of Suleiman the Magnificent in Szigetvár, Hungary: 
Historical, Geophysical and Archeological Investigations. Die Erde Vol. 146, No. 4, pp. 289-303.

Rácz, István (1995): A török világ hagyatéka Magyarországon [The legacy of the Turkish rule in Hungary]. Debrecen, Kossuth Egyetemi Kiadó, 261 pp.

Ruzsás, Lajos-Angyal, Endre (1971): Cserenkó és Budina [Črnko and Budina]. Századok Vol. 105 , No. 1, pp. 57-69.

Şenyurt, Oya (2012): Kosova'da Murad Hüdavendigâr Türbesi ve Ek Yapıları. METU Journal of the Faculty of Architecture Vol. 29, No. 2, pp. 285-311.

Sterner, Dávid (2016): A turbéki kegytemplom és búcsú története a 20. században [History of the shrine and saint's day in Turbék in the 20th century]. In: Varga, Sz. (ed.): Szüz Mária segitségével. A turbéki Mária-kegyhely története [With the help of Virgin Mary: a history of the shrine to Virgin Mary at Turbék]. Budapest, MTA Bölcsészettudományi Kutatóközpont, pp. $43-70$.

Sudár, Balázs (2013): A pécsi Idrisz Baba-türbe [The Idris Baba türbe in Pécs]. Budapest, Forster Gyula Nemzeti Örökséggazdálkodási és Szolgáltatási Központ, 120 pp.

Szakály, Ferenc (1981): Magyar adóztatás a török hódoltságban [Hungarian taxation in the territory under Ottoman rule]. Budapest, Akadémiai Kiadó, 485 pp.

Takáts, Miklós (2007): A rigómezei csata és mítosza [The battle at Kosovo Polje and its mythos]. História Vol. 29, No. 2, p. 5.

Takáts, Sándor (1927): Nagy Szolimán császár sírja [The tomb of Süleyman the Magnificent]. In: Takács, Sándor: A török hódoltság korából [About the Turkish era in Hungary]. [Budapest,] Genius (Rajzok a török világból IV), pp. 123-132.

Tracy, James D. (2013): The Road to Szigetvár: Ferdinand I's Defense of his Hungarian Frontier, 1548-1564. The Austrian History Yearbook Vol. 44, pp. 17-36.

Tracy, James D. (2016): Balkan Wars: Habsburg Croatia, Ottoman Bosnia, and Venetian Dalmatia, 1499-1617. Lanham-London, Rowman and Littlefield, VIII + 448 pp.

Varga, Szabolcs (2006): A vár és mezőváros története 1526-1566 között [The history of the fortress and town of Szigetvár between 1526 and 1566]. In: Bősze, Sándor-Ravazdi, László Szita, László (eds): Szigetvár története. Tanulmányok a város múltjából [The history of Szigetvár: Studies on the past of the town]. Szigetvár, Szigetvár Város ÖnkormányzataSzigetvári Várbaráti Kör, pp. 45-91.

Varga, Szabolcs (ed.) (2016): Szüz Mária segitségével. A turbéki Mária-kegyhely története [With the help of Virgin Mary: A history of the shrine to Virgin Mary at Turbék]. Budapest, MTA Bölcsészettudományi Kutatóközpont, 104 pp.

Vatin, Nicolas (1995): Aux origines du pélérinage à Eyüp des sultans ottomans. Turcica Vol. 27, pp. $91-99$.

Vatin, Nicolas (2005): Un türbe sans maitre. Note sur la fondation et la destination du türbe de Soliman-le-Magnifique à Szigetvár. Turcica Vol. 37, pp. 9-42.

Vatin, Nicolas (2008): Egy türbe, amelyben nem nyugszik senki. Megjegyzések Nagy Szülejmán szigetvári sírkápolnájának alapításához és rendeltetéséhez [A türbe without owner: some notes on the foundation and destiny of Süleyman the Magnificent's tomb in Szigetvár]. Keletkutatás Spring-Autumn 2008, pp. 53-72.

Vatin, Nicolas (2018): On Süleyman the Magnificent's Death and Burials. In: Fodor, Pál (ed.): Szigetvár, 1566. Commemorative Conference on the Siege of Szigetvár and Süleyman the Magnificent's and Miklós Zrínyi's Death. Proceedings.

Y1lmaz, Mehmet Emin (2015): Sigetvar'da Türk Mimârîsi. Türbe Palankasi: Kānûnî Sultan Süleyman'ın Makām Türbesi. İstanbul, İstanbul Fetih Cemiyeti, 231 pp. 
